\title{
Elevated 14,15- epoxyeicosatrienoic acid by increasing of cytochrome P450 2C8, 2C9 and 2J2 and decreasing of soluble epoxide hydrolase associated with aggressiveness of human breast cancer
}

Xiaolong Wei ${ }^{1}$, Donghong Zhang ${ }^{2 *}$, Xiaowei $\mathrm{Dou}^{3}$, Na Niư ${ }^{4}$, Wenhe Huang ${ }^{3}$, Jingwen Bai ${ }^{3}$ and Guojun Zhang ${ }^{3^{*}}$

\begin{abstract}
Background: Epoxyeicosatrienoic acids (EETs) are derived from arachidonic acid by cytochrome P450 (CYP) and metabolized by soluble epoxide hydrolase (sEH). EETs have been associated with cardiovascular disease, diabetes and several cancer diseases. However, the distribution in tissue and role of CYP2C8, 2C9, 2J2 and sEH in human breast carcinogenesis remains uncertain.

Methods: Breast cancer (BC) and adjacent noncancerous tissue was obtained from 40 breast cancer patients in the Chaoshan region in China from 2010 to 2012. The level of 14,15-EET/14,15-DHET in BC patients was detected by ELISA; the expression and distribution of CYP2C8, 2C9, 2J2 and sEH was determined by quantitative RT-PCR and immunohistochemical staining; and cell proliferation and migration was analyzed by MTT and transwell assays, respectively.

Results: The median 14,15-EET and 14,15-EET/DHET level was 2.5-fold higher in BC than noncancerous tissue. The mRNA and protein levels of CYP2C8, $2 \mathrm{C} 9$ and $2 \mathrm{~J} 2$ were higher, and sEH was lower in $\mathrm{BC}$ than noncancerous tissue. Furthermore, CYP2C8 and 2C9 protein levels positively correlated with Ki67 status, and CYP2J2 levels positively correlated with histological grade and tumor size. The $\mathrm{sEH}$ protein level negatively correlated with tumor size, estrogen receptors and Ki67. In MDA-MB-231 cells, siRNA knockdown of CYP2C8, 2C9 or 2J2 reduced cell proliferation, by 24.5\%, 29.13\%, or $22.7 \%$ and decreased cell migration by $49.1 \%, 44.9 \%$, and $50.9 \%$, respectively. Similarly, with adenovirus overexpression of $\mathrm{sEH}$, both cell proliferation and migration rates were reduced by $31.4 \%$ and $45.8 \%$, respectively.

Conclusions: The present study shows that elevated EET levels in BC tissues are associated with upregulation of CYP2C8, $2 \mathrm{C}$, and 2J2, and downregulation of $\mathrm{sEH}$, and are also associated with aggressive cell behavior in BC patients.
\end{abstract}

Keywords: Soluble epoxide hydrolase, Cytochrome P450, Breast cancer, Proliferation, Migration

\footnotetext{
*Correspondence: donghong1228@163.com; guoj_zhang@yahoo.com

${ }^{2}$ Department of Clinical Laboratory, Peking Union Medical College Hospital,

Beijing 100730, China

${ }^{3}$ The Breast Center, Cancer Hospital of Shantou University Medical College,

Shantou 515031, Guangdong, China

Full list of author information is available at the end of the article
}

\section{Biomed Central}

(c) 2014 Wei et al.; licensee BioMed Central Ltd. This is an Open Access article distributed under the terms of the Creative Commons Attribution License (http://creativecommons.org/licenses/by/4.0), which permits unrestricted use, distribution, and reproduction in any medium, provided the original work is properly credited. The Creative Commons Public Domain Dedication waiver (http://creativecommons.org/publicdomain/zero/1.0/) applies to the data made available in this article, unless otherwise stated. 


\section{Background}

Breast cancer (BC) is the most frequently diagnosed cancer and the leading cause of cancer deaths in women in both developed and developing countries worldwide. In 2008, 1.38 million new cases of $\mathrm{BC}$ were diagnosed and 458,400 people died due to $\mathrm{BC}$ [1]. The etiology of $\mathrm{BC}$ appears to be related to a long menstrual history, nulliparity, recent use of postmenopausal hormone therapy or oral contraceptives, late age at first birth and alcohol consumption [2]. However, substantial numbers of patients still experience metastatic disease, and further improvements in survival depend on a better understanding and identification of cellular targets within the malignant cell for novel therapeutic development and for targeting of optimal therapies. Thus, the exact causes of $\mathrm{BC}$ and its malignant potential are still unclear.

Epoxyeicosatrienoic acids (EETs), derived from arachidonic acid by cytochrome P450 (CYP), promote the pathogenesis of various human cancers [3-7]. Four regioisomeric EETs (5,6-EET, 8,9-EET, 11,12-EET, and 14,15-EET) are active lipid signaling molecules and are anti-inflammatory, proliferative, and angiogenic, and easily spread within several tissues under both physiologic and pathologic conditions. In humans, CYP2C8, 2C9 and 2J2 subfamily members participate in the synthesis of EETs, which are then quickly metabolized by soluble epoxide hydrolase $(\mathrm{sEH})$ into their respective diols in most tissues $[8,9]$. Thus, the balance of CYP2C8, 2C9, and 2J2, as well as $\mathrm{sEH}$ expression is responsible for sustaining EET concentration.

CYP2C8, 2C9, 2J2 and sEH expression has been detected in several tumor tissues and cells, which supports a role for EETs in cancer. Both CYP2C8 and 2C9 are highly expressed in human malignant neoplasms, such as renal carcinoma, lung adenocarcinoma (but not lung squamous cell carcinoma), ductal breast carcinoma, colon adenocarcinoma, basal cell carcinoma, bladder transitional cell carcinoma, ovarian adenocarcinoma, endometrial carcinoma, and prostate adenocarcinoma. In contrast, CYP2C8 expression has been found to be downregulated five-fold in esophageal adenocarcinoma as compared with paracancerous tissue [10]. CYP2J2 expression is elevated in human malignant tumors, such as esophageal, liver, breast, lung, and colorectal cancers, and high levels of EETs are detected in urine and blood of patients with these cancers $[3,11]$. In contrast, pancreatic or prostate adenocarcinoma or BC tissue do not show CYP2J2 expression, and the enzyme is detected in less than $50 \%$ of lung squamous cell carcinoma and less than $15 \%$ of lung adenocarcinoma samples $[10,12,13]$. This decrease in arachidonic acid epoxidation in certain tumors may allow arachidonic acid to be metabolized to other eicosanoids [12]. Loss of $\mathrm{sEH}$ has been reported in renal tumors, hepatocellular carcinoma and hepatoma cells $[10,14,15]$, which would result in an enhanced role of EETs in carcinogenesis.
However, upregulation of sEH expression has been found in other types of cancers, such as seminoma, cholangiocarcinoma, and advanced ovarian cancer, as compared with normal tissue or early-stage cancer $[3,10,11]$.

Although many studies have focused on EET synthesis and metabolic enzymes in several cancers, the characteristics and roles of EET isoforms such as $\mathrm{CYP} 2 \mathrm{C} 8,2 \mathrm{C} 9$, and $2 \mathrm{~J} 2$, and $\mathrm{sEH}$ in $\mathrm{BC}$ remains poorly understood. A recent microarray assay of $\mathrm{BC}$ tissue showed CYP2C expression in $80 \%$ of the tissues, with weak or moderate immunoreactivity [13], whereas other studies found high prevalence and modest or strong immunoreactivity $[3,11]$. We conducted a retrospective investigation of the level of EET and expression and distribution of CYP2C8, 2C9, and 2J2 and $\mathrm{SEH}$ in human $\mathrm{BC}$ tissue and adjacent noncancerous tissue. We further investigated the role of EETs and $\mathrm{SEH}$ during breast cancer proliferation and migration.

\section{Methods}

\section{Patients}

The study protocol was performed according to the Declaration of Helsinki and was approved by the Ethics Committee of the Cancer Hospital of Shantou University Medical College. All patients were from the Shantou region of China and gave their signed informed consent for the use of biological samples.

All patients underwent modified radical mastectomy or mastectomy, and no patients received lumpectomy. Fresh noncancerous tissues were collected at least $5 \mathrm{~cm}$ away from the margins of tumors for paired malignant lesions from 40 patients (mean age $44.5 \pm 8.7$ years) in the Cancer Hospital of Shantou University Medical College from 2010 to 2012. Non-cancerous tissue, confirmed by a pathologist, was defined as normal breast tissue not presented with ductal carcinoma in situ (DCIS), atypical hyperplasia or benign breast disease. Changes in tumor size, node metastasis and histological grade were determined according to the World Health Organization histological classification criteria [16].

\section{4,15-EET/DHET detection}

Episomal and esterified 14,15-DHET (including episomal and transformed DHET from 14,15-EET by sEH) in BC tissues was determined by use of an ELISA kit (Detroit R\&D, USA). Briefly, we homogenized $30 \mathrm{mg}$ tissue in $0.4 \mathrm{~mL}$ of $\mathrm{H}_{2} \mathrm{O}$, containing $0.001 \mathrm{mg}$ TPP (triphenylphosphine, an antioxidant), for all tumor and non-tumor tissues before ethyl acetate extraction. Total protein concentration was measured with a BSA kit according to the protocol (Takara Biotechnology [DALIAN] Co.) and used to normalize EET and DHET measurements. Ethyl acetate extracts were incubated in ethanol and acetic acid for $18 \mathrm{~h}$ at room temperature to allow complete EET hydrolysis to DHET. Then, $130 \mathrm{uL}$ of Sample Dilution Buffer was added 
to make a stock sample solution. The final $\mathrm{pH}$ was adjusted to $\mathrm{pH}$ 7.4, if necessary, then DHET, which included DHET converted from EET, was measured using a 14,15DHET ELISA kit. At the same time, the DHET level was measured without hydrolysis of EET in the same sample, then subtracted from the EET + DHET level to obtain the EET level in the sample. Inability to detect levels of EETs indicated that EET was totally hydrolyzed to DHET. The efficiency of conversion of EET to DHET according to the free of EET formation activity measurement after the EET hydrolyzed to DHET by ethanol and acetic acid.

\section{Immunohistochemical (IHC) staining}

After excision, clinical samples were fixed immediately in $4 \%$ paraformaldehyde for $24 \mathrm{hr}$, embedded in paraffin and sectioned at $4 \mu \mathrm{m}$ thickness for IHC staining with primary antibody for CYP2C8 (1:100, Proteintech Group, Chicago, IL, USA), 2C9 (1:100, Biosynthesis, Beijing), and 2J2 (1:100, Abgent, San Diego, CA), as well as for sEH (1:100, Santa Cruz Biotechnology, Santa Cruz, CA) as described $[13,17]$. IgG or phosphate-buffered saline (PBS) was a negative or blank control, respectively. Then, the slides were incubated with polyclonal peroxidase-conjugated anti-mouse/rabbit IgG (PV9000; Zymed Laboratories, South San Francisco, CA). Sections were stained with $100 \mu \mathrm{l}$ AEC chromogen (Maxim.bio Co.) and restained with haematoxylin for visualization of nuclei.

The scoring of positive immunoreactivity was as described previously $[4,18]$ with modifications: $0,<25 \% ; 1$, $25-50 \% ; 2,50-75 \% ; 3,>75 \%$. The intensity of staining was scored as 0 , absence of signal; 2 , low-intensity signal (light red); 2, moderate-intensity signal (red); and 3, highintensity signal (dark red). The final score for each case was the total of the frequency and intensity scores, with the following classification: 0 or 1 , negative $(-)$; 2 or 3 , moderately positive $(+)$; and 4 to 6 , highly positive $(++)$.

\section{Cell culture, transfection and infection}

Human BC MDA-MB-231 cells were maintained in DMEM (Invitrogen, Carlsbad, CA) supplemented with $10 \%$ heat-inactivated fetal bovine serum at $37^{\circ} \mathrm{C}$ in a humidified atmosphere containing $5 \% \mathrm{CO}_{2}$. After culture for $24 \mathrm{hr}$ at $50 \%$ to $60 \%$ density, cells were transfected with $40 \mu \mathrm{mol} / \mathrm{L}$ siRNA pools for CYP2C8, 2C9 or 2J2 by the Jet PEI method (Polyplus, San Marcos, CA) or infected with adenovirus sEH (Ad-sEH) [19], a recombinant Ad expressing human-EPXH2. Ad-GFP was an infection control.

\section{Quantitative reverse transcription-PCR (qRT-PCR)}

Total RNA was isolated from tissue and cells with use of TRIzol reagent (Invitrogen), and $0.5 \mu \mathrm{g}$ RNA was converted to cDNA with the SuperScript II Reverse Transcriptase kit (Invitrogen). Primers for CYP2C8, 2C9, 2J2, sEH and $\beta$-actin were as we described previously [17]. qRT-PCR amplification involved the PrimeScript Real-Time RT-PCR reagent kit (Takara Biotechnology [DALIAN] Co.) and Applied Biosystems Prism 7300 (Invitrogen). DNasetreated RNA was amplified without reverse transcriptase as a negative control. Human hepatocellular carcinoma tissue RNA was a positive control and water was a blank control. Amplification of $\beta$-actin was an internal control. The relative expressions of CYPs and sEH were normalized to their corresponding normal control tissue.

\section{MTT assay}

MDA-MB-231 cells were inoculated at 5000 cells per well of a 96-well plate, allowed to attach for $24 \mathrm{hr}$, and then treated with siRNA or Ad-sEH/Ad-GFP at the indicated amounts for another $24 \mathrm{hr}$. Cell proliferation was analyzed by use of the MTT Cell Proliferation and Cytotoxicity Assay Kit (Beyotime, China). The corrected absorbance of each sample was calculated by comparison with that of the siRNA control or Ad-GFP as an infection control.

\section{Cell transwell assay for migration}

MDA-MB-231 cells treated with siRNA or Ad-sEH/AdGFP were inoculated at $2 \times 10^{5}$ in transwell inserts with $0.8 \mu \mathrm{m}$ pore size (Corning, New York, USA) in 24-well plates for $24 \mathrm{~h}$. Cells in the bottom inside of the membranes were removed. Migrating cells on the outside membrane were washed and stained with crystal violet for $10 \mathrm{~min}$. The number of migrating cells was measured by counting 5 randomly chosen fields under a microscope [20].

\section{Statistical analysis}

Statistical analysis involved use of SPSS 16.0 (SPSS Inc., Chicago, IL). The normality of variables was assessed. The Mann-Whitney two-sample test was used to assess differences in 14,15-EET levels and mRNA expression of CYP2C8, 2C9, and 2J2, as well as $\mathrm{sEH}$ in $\mathrm{BC}$ and adjacent noncancerous tissue. Spearman correlation was used to analyze the correlation of clinicopathological variables and CYP2C8, 2C9, and 2J2, as well as sEH protein expression. Student's t test was used for statistical analysis of cell proliferation and migration assays. Data are expressed as median (interquartile range [IQR]) or mean $\pm \mathrm{SD}$. Each experiment was performed at least in triplicate. $\mathrm{P}<0.05$ was considered statistically significant.

\section{Results}

14,15-EET levels in $B C$ and noncancerous human tissue EETs and their synthetic and metabolic enzymes (CYP2C8, $2 \mathrm{C} 9,2 \mathrm{~J} 2$ and $\mathrm{sEH})$ promote angiogenesis, inflammation, and carcinogenesis $[5,6,17]$. We detected the 14,15-EET level in cancer tissue from $40 \mathrm{BC}$ patients. The median 14,15-EET level was 2.5 -fold higher in $\mathrm{BC}$ tissue than adjacent noncancerous tissue (4145.9 [IQR 1299.8-6500.0] 
Figure 1 Intracellular levels of 14,15-EET (A), 14,15-EET/DHET (B) and total 14,15-DHET (C) in breast cancer and paired adjacent noncancerous regions. Boxes and whiskers represent the 25th-75th and 10th-90th percentiles, respectively; the median is the central line in each box. The P value was calculated by the Mann-Whitney two-sample test.

vs. 1634.4 [1092.5-3844.7] $\mathrm{ng} / \mathrm{mg}$ protein; $\mathrm{p}=0.01$ ) (Figure 1A) and the median ratio of 14,15-EET to episomal 14,15-DHET was higher in BC tissue than noncancerous tissue $(0.80$ [0.64-0.85] vs. 0.58 [0.37-0.75]; $\mathrm{p}<0.001$ ) (Figure 1B), with no difference in total 14,15DHET level (including episomal and transformed DHET from 14,15-EET by sEH) (Figure 1C).

Expression of enzymes for EET synthesis and degradation, and their association with clinicopathological variables in $\mathrm{BC}$ patients

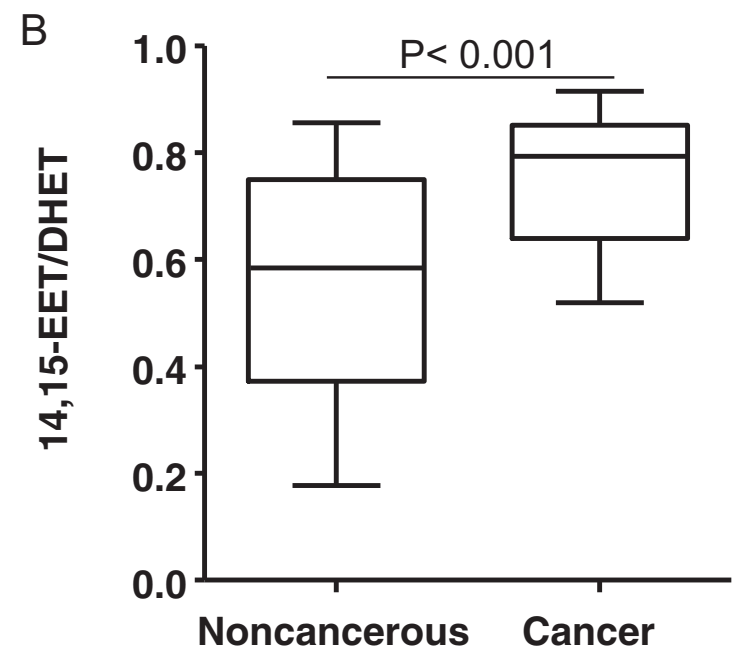

The mRNA levels of enzymes responsible for EET synthesis ranged from 4.4- to 7.5-fold greater BC than noncancerous tissue: CYP2C8 (4.40-fold), 2C9 (7.55-fold) and 2J2 (7.19-fold) (Figure 2). In contrast, sEH, responsible for EET degradation, was reduced (52.8\% of normal) (Figure 2). Also, CYP2C9 protein expression was the most prevalent in the 40 cases of $\mathrm{BC}$ and adjacent noncancerous tissue, accounting for about $60 \%(24 / 40)$ and $45 \%$ (18/40), respectively, of the enzymes responsible for EET synthesis. Equal protein expression was observed for CYP2C8 and 2J2 in BC (30\%) and noncancerous (10\%) tissue (Table 1). The proportion of sEH protein expression was $40 \%(16 / 40)$ and $60 \%(24 / 40)$ in BC and adjacent noncancerous tissue, respectively. In addition, immunoreactivity was increased for CYP2C8 and 2J2 but not 2C9 and decreased for sEH in BC tissue (Table 1). These results indicate that, consistent with the elevated EET levels reported above, the enzymes responsible for EET synthesis are elevated, whereas the enzyme responsible for EET degradation is decreased in $\mathrm{BC}$ tissue.

The CYP2C8 protein level correlated with estrogen receptors (ER) and Ki67 status ( $\mathrm{P}=0.011$ and $\mathrm{P}=0.037$, respectively); the CYP2C9 level correlated with Ki67 status ( $\mathrm{P}=0.007)$; the CYP2J2 level correlated with histological grade and tumor size $(\mathrm{P}=0.036$ and $\mathrm{P}=0.047$, respectively); and $\mathrm{sEH}$ level was negatively correlated with tumor size, $E R$ and Ki67 status $(P=0.021 ; P=0.003$ and $P<0.001$, respectively) (Table 2). No relationship was found with age, lymph-node metastasis, histological grade, C-erbB-2 and progesterone receptor (PR) expression.

\section{Effect of CYP450 and sEH on proliferation and migration of $B C$ cells}

To further investigate the functional role of $\mathrm{CYP} 2 \mathrm{C} 8,2 \mathrm{C}$, and $2 \mathrm{~J} 2$ and $\mathrm{sEH}$ in $\mathrm{BC}$ cells, we transfected CYP2C8, 2C9 and 2J2 siRNA into MDA-MB-231 cells. At $24 \mathrm{~h}$ 


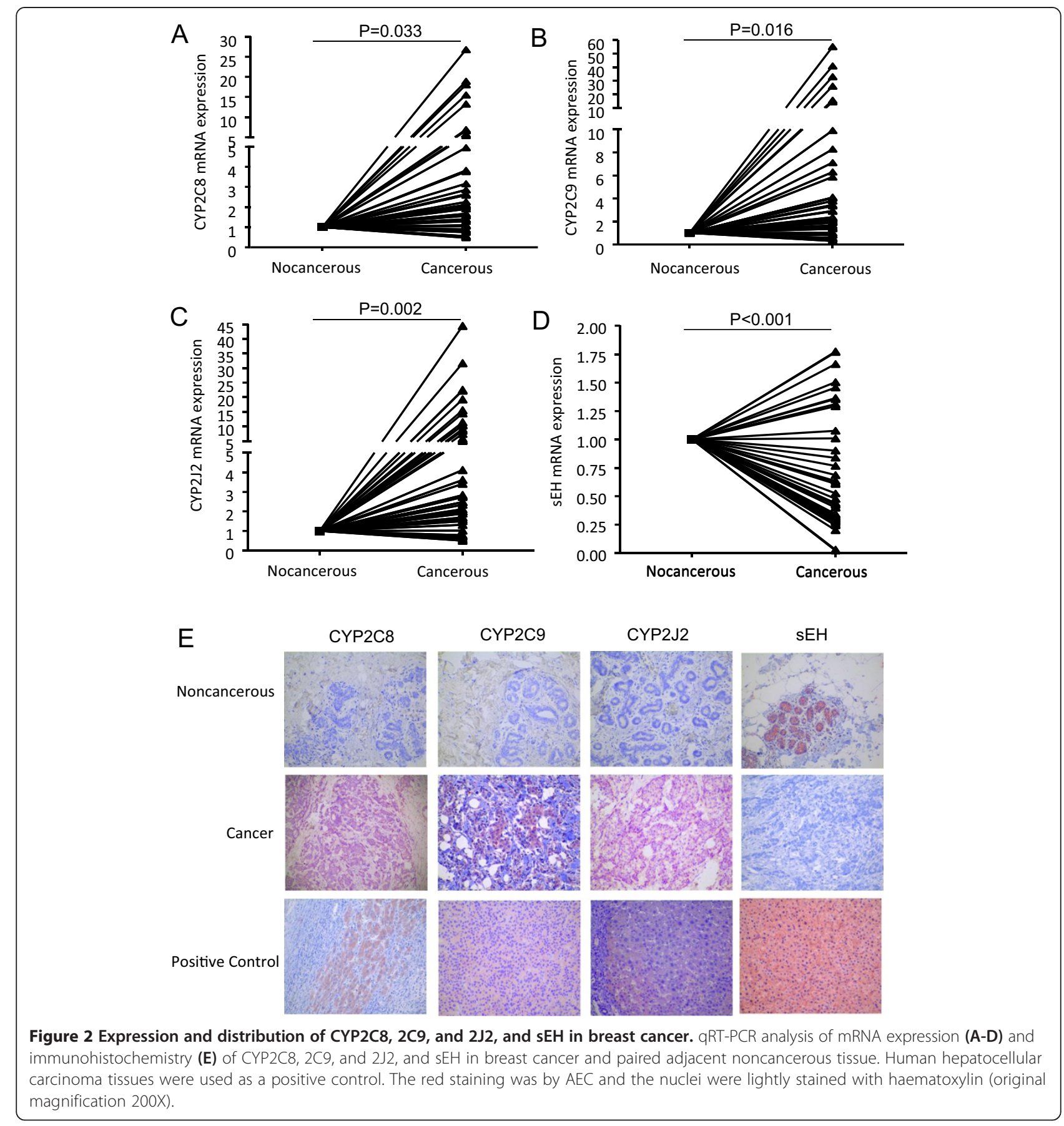

after transfection, mRNA expression was knocked down $57.9 \pm 10.6 \%, 48.0 \pm 4.5 \%$ and $63.5 \pm 3.6 \%$, and cell proliferation decreased by $24.5 \pm 7.2 \%, 29.1 \pm 5.0 \%$, and $22.7 \pm 3.5 \%$, respectively (Figure 3C). Meanwhile, the proportion of migrating cells was also decreased by about $49.1 \pm 10.2 \%$, $44.9 \pm 7.9 \%$, and $50.9 \pm 11.1 \%$, respectively (Figure 3D, E). To overexpress sEH exogenously, we infected MDA-MB231 cells with Ad-sEH. At $24 \mathrm{hr}$ after infection, sEH mRNA was approximately 125.3-fold higher with Ad-sEH than Ad-GFP infection (Figure 3B). With Ad-sEH infection, cell proliferation was decreased about $31.4 \pm 5.3 \%$ as compared with Ad-GFP transfection (Figure 3C) and the proportion of migrating cells was decreased about $45.8 \pm 9.1 \%$, (Figure 3E).

\section{Discussion}

The level of EETs, as well as their synthetic and metabolic enzymes, has attracted great interest as potential therapeutic targets for renal disease, cardiovascular disease, inflammation and cancer $[3,6,9,21]$. Indeed, previous 
Table 1 EET-related gene expression in noncancerous tissue and adjacent breast cancer tissue

\begin{tabular}{|c|c|c|c|c|c|}
\hline \multirow{2}{*}{$\begin{array}{l}\text { EET-related } \\
\text { genes }\end{array}$} & \multirow{2}{*}{$\begin{array}{c}\text { Non-cancerous } \\
\text { tissue }\end{array}$} & \multicolumn{3}{|c|}{ Breast cancer tissue, no. of samples (\%) } & \multirow[t]{2}{*}{ P value* } \\
\hline & & - & + & ++ & \\
\hline \multirow[t]{3}{*}{ CYP2C8 } & - & $28(70 \%)$ & $4(10 \%)$ & $4(10 \%)$ & 0.019 \\
\hline & + & 0 & 0 & $2(5 \%)$ & \\
\hline & ++ & 0 & 0 & $2(5 \%)$ & \\
\hline \multirow[t]{3}{*}{ CYP2C9 } & - & $12(30 \%)$ & $6(15 \%)$ & $4(10 \%)$ & 0.094 \\
\hline & + & $4(10 \%)$ & $2(5 \%)$ & $6(15 \%)$ & \\
\hline & ++ & 0 & $2(5 \%)$ & $4(10 \%)$ & \\
\hline \multirow[t]{3}{*}{ CYP2J2 } & - & $28(70 \%)$ & $6(15 \%)$ & $2(5 \%)$ & 0.019 \\
\hline & + & 0 & 0 & $2(5 \%)$ & \\
\hline & ++ & 0 & 0 & $2(5 \%)$ & \\
\hline \multirow[t]{3}{*}{ sEH } & - & $10(25 \%)$ & $6(15 \%)$ & 0 & 0.034 \\
\hline & + & $6(15 \%)$ & $2(5 \%)$ & $4(10 \%)$ & \\
\hline & ++ & $8(20 \%)$ & $2(5 \%)$ & $2(5 \%)$ & \\
\hline
\end{tabular}

Sum of frequency and intensity scores: 0 or 1 , negative $(-) ; 2$ or 3 , moderately positive $(+) ; 4$ to 6 , highly positive (++).

*Spearman correlation was used to analyze the correlation of clinicopathological variables and EET-related genes expression.

in vivo and in vitro studies, including ours, have shown that $\mathrm{CYP} 2 \mathrm{C} 8,2 \mathrm{C}$, and 2JC promote cancer cell proliferation, migration, angiogenesis, survival and invasion in several types of cancer such as hepatocellular carcinoma, esophageal carcinoma, and malignant hematologic disease $[5,6,17]$. However, the characteristics of EET expression and their synthetic and metabolic enzymes are not clear in
BC. In the present study, we find a high level of 14,15EET with increasing CYP2C8, 2C9 and 2J2 expression, and decreasing $\mathrm{sEH}$ mRNA and protein expression in $\mathrm{BC}$ as compared with adjacent noncancerous tissue. We further show that knockdown of CYP2C8, 2C9 and 2J2 or overexpression of $\mathrm{sEH}$ inhibits the proliferation and migration of BC cells.

Table 2 Relationship of EET-related gene expression and clinical characteristics of BC patients

\begin{tabular}{|c|c|c|c|c|c|c|c|c|c|c|c|c|c|}
\hline \multicolumn{2}{|l|}{ Variable } & \multicolumn{3}{|c|}{ CYP2C8 } & \multicolumn{3}{|c|}{ CYP2C9 } & \multicolumn{3}{|c|}{ CYP2J2 } & \multicolumn{3}{|c|}{ sEH } \\
\hline & & - & + & P value* & - & + & P value* & - & + & P value* & - & + & P value* \\
\hline \multirow[t]{2}{*}{ Age, years } & $\leq 50$ & 12 & 4 & 0.573 & 8 & 8 & 0.292 & 12 & 4 & 0.573 & 12 & 10 & 0.618 \\
\hline & $>50$ & 16 & 8 & & 8 & 16 & & 16 & 8 & & 12 & 6 & \\
\hline \multirow[t]{3}{*}{ Histological grade } & I & 8 & 2 & 0.821 & 8 & 6 & 0.879 & 14 & 2 & 0.036 & 6 & 4 & 0.131 \\
\hline & $\|$ & 12 & 6 & & 6 & 8 & & 10 & 4 & & 8 & 10 & \\
\hline & III & 8 & 4 & & 2 & 10 & & 4 & 6 & & 10 & 2 & \\
\hline \multirow[t]{3}{*}{ Tumor size, cm } & $\leq 2$ & 8 & 0 & 0.058 & 6 & 3 & 0.089 & 9 & 1 & 0.047 & 2 & 7 & 0.021 \\
\hline & $2-5$ & 18 & 10 & & 10 & 17 & & 17 & 7 & & 20 & 7 & \\
\hline & $\geq 5$ & 2 & 2 & & 0 & 4 & & 2 & 4 & & 2 & 2 & \\
\hline \multirow[t]{2}{*}{ Lymph node metastasis } & Negative & 14 & 4 & 0.332 & 12 & 12 & 0.114 & 19 & 5 & 0.166 & 10 & 6 & 0.792 \\
\hline & Positive & 14 & 8 & & 4 & 12 & & 9 & 7 & & 14 & 10 & \\
\hline \multirow[t]{2}{*}{ ER status } & - & 6 & 8 & 0.011 & 4 & 10 & 0.279 & 8 & 6 & 0.193 & 4 & 10 & 0.003 \\
\hline & + & 22 & 4 & & 12 & 14 & & 20 & 6 & & 20 & 6 & \\
\hline \multirow[t]{2}{*}{ Ki67 proportion } & $\leq 14 \%$ & 8 & 8 & 0.037 & 2 & 14 & 0.007 & 10 & 6 & 0.49 & 4 & 12 & $<0.001$ \\
\hline & $>14 \%$ & 20 & 4 & & 14 & 10 & & 18 & 6 & & 20 & 4 & \\
\hline \multirow[t]{2}{*}{ C-erb-B2 staining } & $-/+$ & 22 & 6 & 0.13 & 14 & 14 & 0.079 & 24 & 8 & 0.221 & 20 & 10 & 0.159 \\
\hline & $++/+++$ & 6 & 6 & & 2 & 10 & & 4 & 4 & & 4 & 6 & \\
\hline \multirow[t]{2}{*}{ PR status } & - & 6 & 2 & 1 & 2 & 6 & 0.439 & 8 & 0 & 0.079 & 8 & 5 & 0.89 \\
\hline & + & 22 & 10 & & 14 & 18 & & 20 & 12 & & 16 & 11 & \\
\hline
\end{tabular}



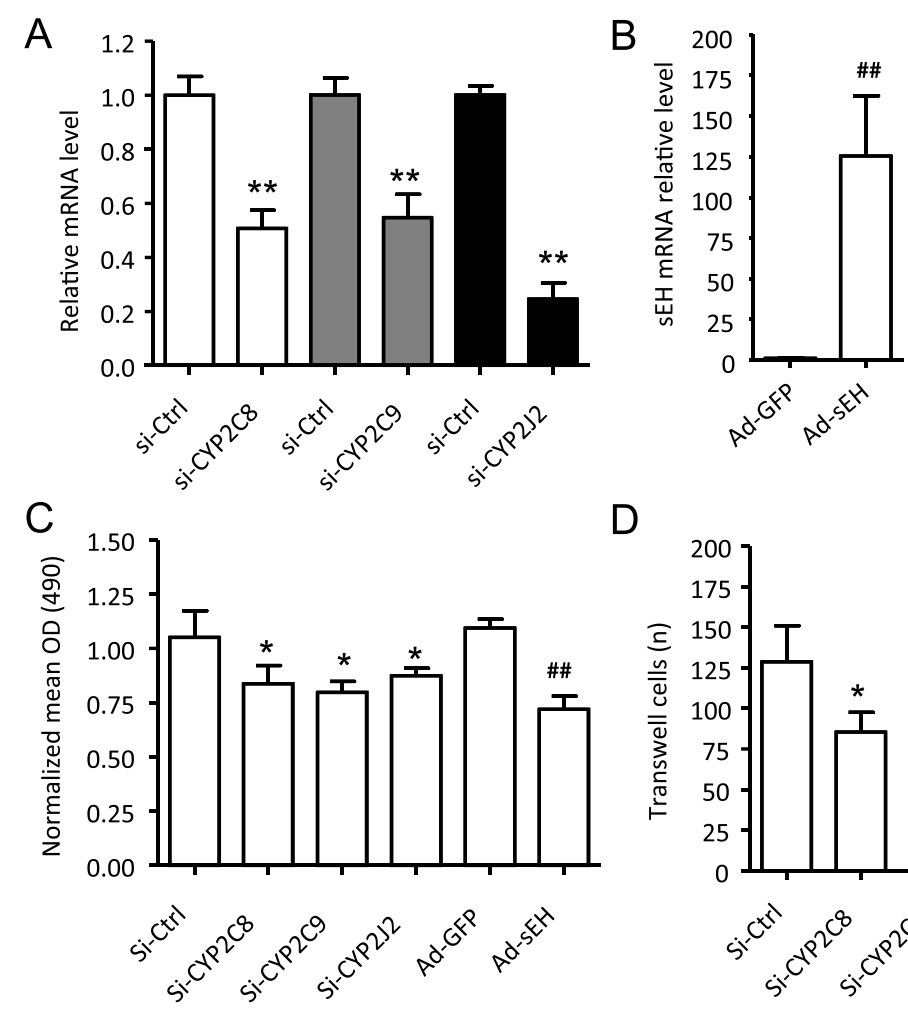

D
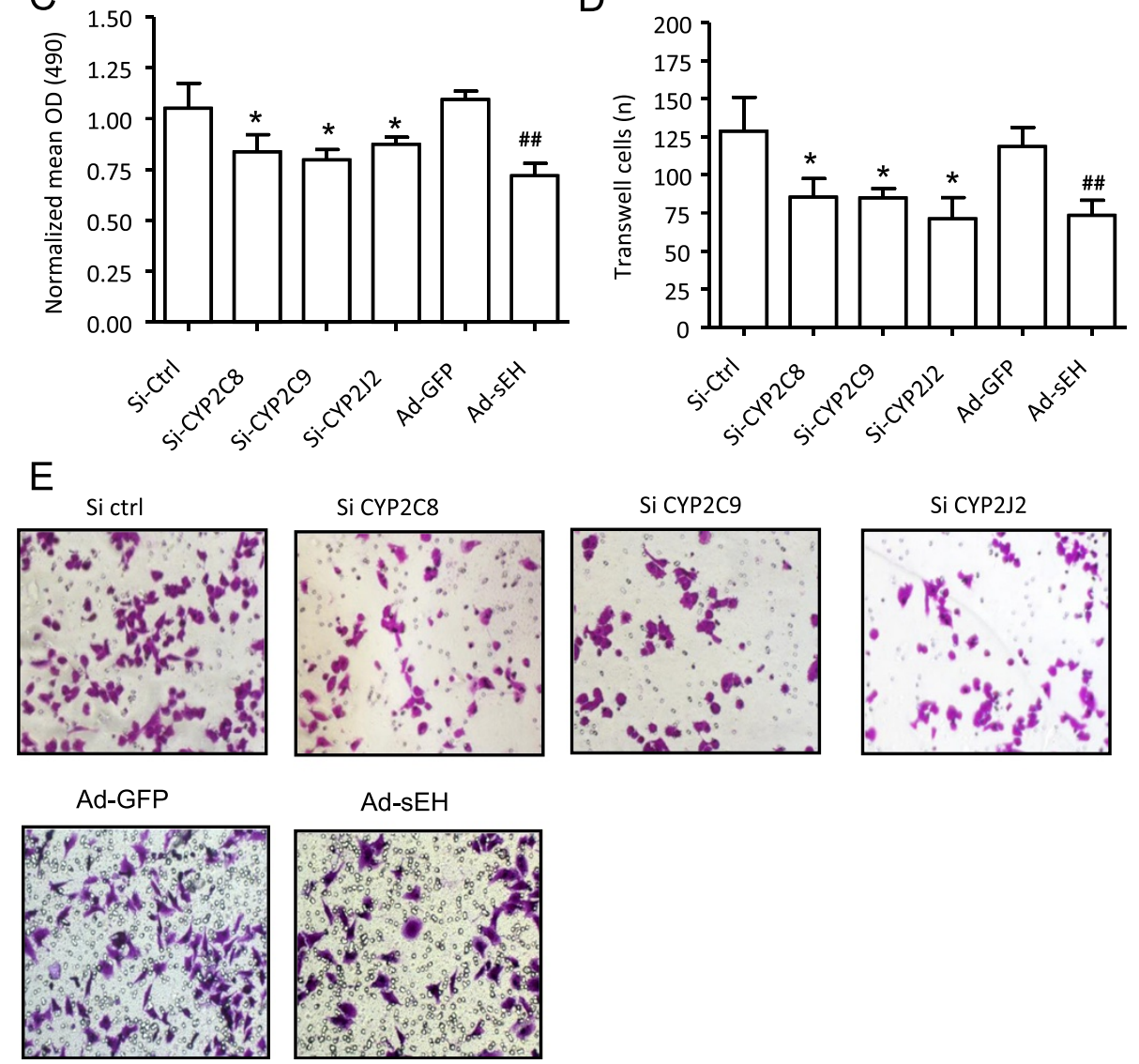

Figure 3 Blockage of cancer-derived EETs by siRNA targeting CYP or overexpression of sEH inhibits proliferation and migration of breast cancer cells. RT-PCR analysis of mRNA expression of CYP2C8, 2C9, and 2J2, and sEH in MDA-MB-231 cells treated with siRNA (A) or adenovirus-sEH (B) for 24 hr. (C) MTT assay of cell proliferation, expressed as the normalized mean $O_{4}$.90. (D) Transwell assay for cell migration. The number of migrated cells was measured by counting 5 randomly chosen fields under a microscope. (E) Representative transwell assay of cells stained with crystal violet (200X). Data are mean \pm SD from 3 independent experiments each performed in triplicate $\left({ }^{*} \mathrm{P}<0.05 ;{ }^{* *} \mathrm{P}<0.01\right.$ compared with Si-RNA control. ${ }^{\# \#} \mathrm{P}<0.01$ compared with Ad-GFP).

CYP450s were thought to promote cancer progression primarily in the major metabolic organs, such as liver, kidney and epithelium. However, recent studies have detected a sustained high level of EETs by upregulated CYP2C8, 2C9 and 2J2, or downregulated sEH in various cancers such as renal, lung, basal cell, bladder, ovarian, colon, and prostate cell carcinomas [3,7,10,22]. BC tissue shows a relatively high percentage and strong immunopositivity of CYP4X1, 2S1 and 2U among twenty-one P450 panels [13]. CYP3A4 is also a highly active arachidonic acid epoxygenase that promotes Stat3-mediated BC cell growth in part via $( \pm)-14,15$-EET biosynthesis [18]. Similarly, CYP2C is detected in $80 \%$ of BC tissue, based on a recent tissue microarray study [13]. 
We find that CYP2C9 and 2C8 are expressed in 60\% and $30 \%$ of $\mathrm{BC}$ tissue, respectively. Both CYP2C8 and 2C9 protein levels positively correlate with Ki67 status, a biomarker for cell proliferation. The modest immunoreactive staining we find for CYP2J2 protein is consistent with previous studies $[3,10]$. Despite the relatively low CYP2J2 prevalence, CYP2J2 protein expression is positively correlated with histological grade and tumor size, which is consistent with previous in vivo and in vitro studies [3,10,21]. Moreover, sEH expression is lower in BC than adjacent noncancerous tissue and negatively correlates with tumor size, ER and Ki67 expression. The elevated CYP2C8, 2C9, and 2J2 expression observed here may represent aggressiveness of $\mathrm{BC}$ cells and might predict worse cell behavior in $\mathrm{BC}$ patients.

Evidence from Panigrahy and colleagues has shown that elevated EET levels in endothelial cells leads to the development of tumor-associated angiogenesis and promotes metastasis $[6,23]$. In vitro and in vivo studies also indicate that EETs may promote cancer progression by directly inducing cancer cell proliferation, survival, migration, and invasion, by changing the tumor microenvironment (inducing angiogenesis) and/or inducing immunosuppression in an autocrine and/or paracrine manner. This mechanism supports the role of CYP450s as potential tumor-promoting enzymes [3,5]. For example, downregulated CYP2C expression and/or its enzymatic activity may provide a safe and effective strategy to treat non-small cell lung cancer [22]. Treatment of glioblastoma-bearing rats with CYP epoxygenase inhibitors attenuated tumor growth and tumor-associated angiogenesis [24]. Similarly, overexpression of $\mathrm{sEH}$ decreased HepG2 cell proliferation and induced cell cycle arrest [19]. Treating mice with a CYP2J peptide inhibited tumor growth by activating host antitumor immunity at an initial stage of an implanted murine bladder tumor [25]. In our study, consistent with the elevated 14,15-EET levels in BC tissue, elevated CYP2C8, $2 \mathrm{C} 9$ and 2J2 expression and reduced sEH expression might contribute to increased 14,15-EET levels and promote breast carcinogenesis. This result is further supported by our in vitro findings showing that knockdown of CYP2C8, 2C9 or 2J2 and overexpression of sEH inhibits the proliferation and slows the migration of $\mathrm{BC}$ cells.

Although the expression and role of CYP2C8, 2C9, and $2 \mathrm{~J} 2$, and sEH have been reported in several tumors, their regulation is largely unknown. Evidence from our previous study showed that hypermethylation of the $\mathrm{sEH}$ promoter in HepG2 cells suppresses its transcription by an SP-1-dependent mechanism [19]. Human CYP2J2 and $2 \mathrm{C} 8$ are post-transcriptionally regulated by microRNAs let-7b and 103/107, respectively [26,27]. EET receptor(s) have not yet been clearly identified, but the putative GPCR/PPAR/RXR pathway, endothelial growth factor receptor (EGFR) and vascular endothelial growth factor signaling are potential targets for EETs to promote tumor growth and metastasis [28-30]. Multiple pathways, including EGFR/PI3K/Akt, EGFR/mitogen-activated protein kinase, tumor necrosis factor- $\alpha$ and pro-metastatic matrix metalloproteinases are also involved in the mechanism by which EETs induce cancer cell proliferation and survival $[3,7,21]$. Thus, to further understand the molecular and biological mechanisms, and develop EET receptor antagonists as antitumor agents of EETs in malignant diseases, the EET receptor must be identified.

\section{Conclusion}

In conclusion, increased EET levels in $\mathrm{BC}$ might be due to upregulation of $\mathrm{CYP} 2 \mathrm{C} 8,2 \mathrm{C}$, and 2J2 and downregulation of $\mathrm{sEH}$, and knockdown of CYP2C8, 2C9, and 2J2 and overexpression of sEH could partially attenuate the proliferation and migration of $\mathrm{BC}$ cells. These molecules might be novel therapeutic targets for the treatment of $\mathrm{BC}$.

\section{Abbreviations}

EET: Epoxyeicosatrienoic acid; sEH: Soluble epoxide hydrolase; CYP: Cytochrome P450; BC: Breast cancer; ER: Estrogen receptors; PR: Progesterone receptor; IHC: Immunohistochemical.

\section{Competing interests}

The authors declare that they have no competing interests.

\section{Authors' contributions}

Conception and design: DH Z, GJ Z. Development of methodology: XL W, $\mathrm{DH} Z, \mathrm{XW} D, N$ N. Acquisition of data (provided animals acquired and managed patients, provided facilities, etc.): XL W, DH Z, XW D, N N, JW B. Analysis and interpretation of data (e.g., statistical analysis, biostatistics, computational analysis): XL W, DH Z, XW D, N N, WH H, JW B. Writing, review, and/or revision of the manuscript: XL W, DH Z, N N, GJ Z. All authors read and approved the final manuscript.

\section{Acknowledgements}

This work was supported in part by grants from the National Basic Research Program of China (973 Program) (NO. 2011CB707705), the National Natural Science Foundation of China (NO. 31271068, 81320108015, 81302331, 81200224), the Medical Science Research Foundation of Guangdong Province in China (NO. 2012B2012248), PUMC Youth Fund, and the Fundamental Research Funds for the Central Universities (NO. 3332013004). We acknowledge Laura Smales (BioMedEditing, Toronto, Canada) for critical reading of the manuscript.

\section{Author details}

'Department of Pathology, Cancer Hospital of Shantou University Medical College, Shantou 515031, Guangdong, China. ${ }^{2}$ Department of Clinical Laboratory, Peking Union Medical College Hospital, Beijing 100730, China. ${ }^{3}$ The Breast Center, Cancer Hospital of Shantou University Medical College, Shantou 515031, Guangdong, China. ${ }^{4}$ Department of Pathology, Weifang Medical University, Weifang 261042, Shandong, China.

Received: 28 April 2014 Accepted: 4 November 2014

Published: 18 November 2014

\section{References}

1. Jemal A, Bray F, Center MM, Ferlay J, Ward E, Forman D: Global cancer statistics. CA Cancer J Clin 2011, 61(2):69-90.

2. Lizarraga IM, Sugg SL, Weigel RJ, Scott-Conner CE: Review of risk factors for the development of contralateral breast cancer. Am J Surg 2013, 206(5):704-708.

3. Jiang JG, Chen CL, Card JW, Yang S, Chen JX, Fu XN, Ning YG, Xiao X, Zeldin DC, Wang DW: Cytochrome P450 $2 \mathrm{~J} 2$ promotes the neoplastic phenotype of 
carcinoma cells and is up-regulated in human tumors. Cancer Res 2005, 65(11):4707-4715.

4. Zhang D, Zhang Q, Zhou L, Huo L, Zhang Y, Shen Z, Zhu Y: Comparison of prevalence, viral load, physical status and expression of human papillomavirus-16, -18 and -58 in esophageal and cervical cancer: a case-control study. BMC Cancer 2010, 10:650.

5. Panigrahy D, Greene ER, Pozzi A, Wang DW, Zeldin DC: EET signaling in cancer. Cancer Metastasis Rev 2011, 30(3-4):525-540.

6. Panigrahy D, Edin ML, Lee CR, Huang S, Bielenberg DR, Butterfield CE, Barnés CM, Mammoto A, Mammoto T, Luria A, Benny O, Chaponis DM, Dudley AC, Greene ER, Vergilio JA, Pietramaggiori G, Scherer-Pietramaggiori SS, Short SM, Seth M, Lih FB, Tomer KB, Yang J, Schwendener RA, Hammock BD, Falck JR, Manthati VL, Ingber DE, Kaipainen A, D'Amore PA, Kieran MW, et al: Epoxyeicosanoids stimulate multiorgan metastasis and tumor dormancy escape in mice. J Clin Invest 2012, 122(1):178-191.

7. Yang $S$, Lin L, Chen JX, Lee CR, Seubert JM, Wang Y, Wang H, Chao ZR, Tao DD, Gong JP, Lu ZY, Wang DW, Zeldin DC: Cytochrome P-450 epoxygenases protect endothelial cells from apoptosis induced by tumor necrosis factor-alpha via MAPK and PI3K/Akt signaling pathways. Am J Physiol Heart Circ Physiol 2007, 293(1):H142-H151.

8. Guo M, Roman RJ, Falck JR, Edwards PA, Scicli AG: Human U251 glioma cell proliferation is suppressed by HET0016 [N-hydroxy-N'-(4-butyl-2methylphenyl)formamidine], a selective inhibitor of CYP4A. J Pharmacol Exp Ther 2005, 315(2):526-533.

9. Imig JD, Hammock BD: Soluble epoxide hydrolase as a therapeutic target for cardiovascular diseases. Nat Rev Drug Discov 2009, 8(10):794-805.

10. Enayetallah AE, French RA, Grant DF: Distribution of soluble epoxide hydrolase, cytochrome P450 2C8, 2C9 and 2J2 in human malignant neoplasms. J Mol Histol 2006, 37(3-4):133-141.

11. Chen C, Wei X, Rao X, Wu J, Yang S, Chen F, Ma D, Zhou J, Dackor RT, Zeldin DC, Wang DW: Cytochrome P450 $2 \mathrm{~J} 2$ is highly expressed in hematologic malignant diseases and promotes tumor cell growth. J Pharmacol Exp Ther 2011, 336(2):344-355.

12. Leclerc J, Tournel G, Courcot-Ngoubo NE, Pottier N, Lafitte JJ, Jaillard S, Mensier E, Lhermitte M, Broly F, Lo-Guidice JM: Profiling gene expression of whole cytochrome P450 superfamily in human bronchial and peripheral lung tissues: Differential expression in non-small cell lung cancers. Biochimie 2010, 92(3):292-306.

13. Murray GI, Patimalla S, Stewart KN, Miller ID, Heys SD: Profiling the expression of cytochrome P450 in breast cancer. Histopathology 2010, 57(2):202-211.

14. Roques M, Bagrel D, Magdalou J, Siest G: Expression of arylhydrocarbon hydroxylase, epoxide hydrolases, glutathione S-transferase and UDPglucuronosyltransferases in H5-6 hepatoma cells. Gen Pharmacol 1991, 22(4):677-684

15. Yang MD, Wu CC, Chiou SH, Chiu CF, Lin TY, Chiang IP, Chow KC: Reduction of dihydrodiol dehydrogenase expression in resected hepatocellular carcinoma. Oncol Rep 2003, 10(2):271-276.

16. Okumura M, Ohta M, Tateyama H, Nakagawa K, Matsumura A, Maeda H, Tada H, Eimoto T, Matsuda H, Masaoka A: The World Health Organization histologic classification system reflects the oncologic behavior of thymoma: a clinical study of 273 patients. Cancer 2002, 94(3):624-632.

17. Zhang D, Xie X, Chen Y, Hammock BD, Kong W, Zhu Y: Homocysteine upregulates soluble epoxide hydrolase in vascular endothelium in vitro and in vivo. Circ Res 2012, 110(6):808-817.

18. Liu Y, Chen Z, Niu N, Chang Q, Deng R, Korteweg C, Gu J: IgG gene expression and its possible significance in prostate cancers. Prostate 2012, 72(6):690-701.

19. Zhang D, Ai D, Tanaka H, Hammock BD, Zhu Y: DNA methylation of the promoter of soluble epoxide hydrolase silences its expression by an SP-1-dependent mechanism. Biochim Biophys Acta 2010, 1799(9):659-667.

20. Mitra R, Guo Z, Milani M, Mesaros C, Rodriguez M, Nguyen J, Luo X, Clarke D, Lamba J, Schuetz E, Donner DB, Puli N, Falck JR, Capdevila J, Gupta K, Blair IA, Potter DA: CYP3A4 mediates growth of estrogen receptor-positive breast cancer cells in part by inducing nuclear translocation of phospho-Stat3 through biosynthesis of (+/-)-14,15-epoxyeicosatrienoic acid (EET). J Biol Chem 2011, 286(20):17543-17559.

21. Jiang JG, Ning YG, Chen C, Ma D, Liu ZJ, Yang S, Zhou J, Xiao X, Zhang XA, Edin ML, Card JW, Wang J, Zeldin DC, Wang DW: Cytochrome p450 epoxygenase promotes human cancer metastasis. Cancer Res 2007, 67(14):6665-6674.
22. Wang D, Dubois RN: Epoxyeicosatrienoic acids: a double-edged sword in cardiovascular diseases and cancer. J Clin Invest 2012, 122(1):19-22.

23. Zhang D, Chen Y, Xie X, Liu J, Wang Q, Kong W, Zhu Y: Homocysteine activates vascular smooth muscle cells by DNA demethylation of platelet-derived growth factor in endothelial cells. J Mol Cell Cardiol 2012, 53(4):487-496

24. Skrypnyk N, Chen X, Hu W, Su Y, Mont S, Yang S, Gangadhariah M, Wei S, Falck JR, Jat JL, Zent R, Capdevila JH, Pozzi A: PPARalpha Activation Can Help Prevent and Treat Non-Small Cell Lung Cancer. Cancer Res 2014, 74(2):621-631.

25. Zagorac D, Jakovcevic D, Gebremedhin D, Harder DR: Antiangiogenic effect of inhibitors of cytochrome P450 on rats with glioblastoma multiforme. J Cereb Blood Flow Metab 2008, 28(8):1431-1439.

26. Homma S1, Koido S, Sagawa Y, Suzuki H, Komita H, Nagasaki E, Takahara A, Horiguchi-Yamada J, Tajiri H, Zeldin DC, Obata T: Antigenic stimulation with cytochrome P450 $2 \mathrm{~J}$ expressed in mouse hepatocellular carcinoma cells regulates host anti-tumour immunity. Clin Exp Immunol 2009, 156(2):344-352.

27. Chen F, Chen C, Yang S, Gong W, Wang Y, Cianflone K, Tang J, Wang DW: Let-7b inhibits human cancer phenotype by targeting cytochrome P450 epoxygenase 2J2. PLoS One 2012, 7(6):e39197.

28. Zhang SY, Surapureddi S, Coulter S, Ferguson SS, Goldstein JA: Human CYP2C8 is post-transcriptionally regulated by microRNAs 103 and 107 in human liver. Mol Pharmacol 2012, 82(3):529-540.

29. Spector AA: Arachidonic acid cytochrome P450 epoxygenase pathway. J Lipid Res 2009, 50(Suppl):S52-S56.

30. Liu L, Chen C, Gong W, Li Y, Edin ML, Zeldin DC, Wang DW: Epoxyeicosatrienoic acids attenuate reactive oxygen species level, mitochondrial dysfunction, caspase activation, and apoptosis in carcinoma cells treated with arsenic trioxide. J Pharmacol Exp Ther 2011, 339(2):451-463.

doi:10.1186/1471-2407-14-841

Cite this article as: Wei et al:: Elevated 14,15- epoxyeicosatrienoic acid by increasing of cytochrome P450 2C8, 2C9 and $2 \mathrm{~J} 2$ and decreasing of soluble epoxide hydrolase associated with aggressiveness of human breast cancer. BMC Cancer 2014 14:841.

\section{Submit your next manuscript to BioMed Central and take full advantage of:}

- Convenient online submission

- Thorough peer review

- No space constraints or color figure charges

- Immediate publication on acceptance

- Inclusion in PubMed, CAS, Scopus and Google Scholar

- Research which is freely available for redistribution 